\title{
Analisis Faktor-Faktor Kemasan (Packaging) dalam Mempengaruhi Keputusan Pembelian Oleh-Oleh Makanan Khas Tanjungpinang
}

\author{
Iranita

\begin{abstract}
Program Studi Manajemen, Fakultas Ekonomi, Universitas Maritim Raja Ali Haji,
\end{abstract} \\ Tanjungpinang, Kepulauan Riau, Indonesia
}

\begin{abstract}
ABSTRAK : Kecendrungan peningkatan pembelian masyarakat saat ini adalah pada sektor makanan. Seiring dengan itu khususnya pertumbuhan bisnis toko oleh-oleh makanan khas Tanjungpinang yang merupakan bagian wisata kuliner bagi masyarakat local atau wisatawan baik dari dalam negeri maupun dari luar negeri. Salah satu faktor penting kemasan untuk suksesnya suatu produk., maka dalam hal ini pemasar dituntut lebih inovatif dan kreatif sehingga bisa menarik konsumen dalam mempengaruhi konsumen untuk memberikan respon positif dan memperkecil resiko negative pasca konsumsi. Tujuan dari penelitian ini adalah untuk mengetahui peranan faktor kemasan (packaging) dalam mempengaruhi keputusan pembelian oleh-oleh makanan khas Tanjungpinang. Penelitian ini bersifat explanatory research dengan menggunakan analisis faktor. Dalam penelitian ini jumlah variabel yang ditetapkan adalah 9 variabel yang berhubungan dengan faktor faktor kemasan (packaging) dalam mempengaruhi keputusan pembelian oleh-oleh makanan khas Tanjungpinang. Hasil dari penelitian ini adalah faktor produk, pengamanan, ekonomi, saluran distribusi, komunikasi, ergonomic, estetika, identitas, promosi, dan lingkungan merupakan faktor yang mempengaruhi keputusan pembelian oleh-oleh makanan khas Tanjungpinang
\end{abstract}

Kata Kunci: Kemasan Produk, Makanan Khas, Keputusan Pembelian

\begin{abstract}
The increasing likelihood of community buying today is on the food sector. Along with that, especially the growth of the business shop souvenirs typical of Tanjungpinang which is a part of culinary tourism for local people or tourists both from domestic and foreign. One important factor of packaging for the success of a product, then in this case marketers demanded more innovative and creative so that it can attract consumers in influencing consumers to provide a positive response and minimize negative risk of postconsumption. The purpose of this research is to know the role of packaging factor in influencing the decision of purchasing souvenirs from Tanjungpinang. This research is explanatory research using factor analysis. In this study the number of variables set is 9 variables that relate to the packaging factor packaging in influencing the decision of the purchase of souvenirs typical of Tanjungpinang. The results of this research are the product factors, security, economics, distribution channels, communication, ergonomic, aesthetics, identity, promotion, and environment are factors that influence the decision of the purchase of souvenirs typical of Tanjungpinang
\end{abstract}

Keywords: Product Packaging, Specialty Food, Purchasing Decisions

Email Address : iranita@umrah.ac.id

\section{Pendahuluan}

Perubahan yang terjadi saat ini adalah perubahan pola interaksi soSial, perubahan sistem nilai maupun peningkatan mobilitas fisik. Timbulnya perubahan sosial ini bersumber dari kemajuan teknologi, kemajuan telekomunikasi, peningkatan pendapatan atau ekonomi, dan perbaikan infrastruktur. Perubahan ini memberi dampak pada perilaku konsumen produk. Hal ini membuat kecendrungan berbelanja dengan mempertimbangkan waktu dan kemudahan seiring dengan meningkatnya swalayan atau counter di kota-kota besar.

Lembaga survey asal Amerika, Nielsan menyatakan bahwa trend belanja masyarakat Indonesia lebih mementingkan kebutuhan makanan dibandingkan dengan yang lain. Dalam survey 
yang dilakukan pada 5 (lima) kota besar (Jakarta, Surabaya, Medan, Bandung, Batam) disimpulkan bahwa penjualan sektor makanan pada Januari 2018 meningkat hingga 46 persen. Sektor makanan masih menyokong 26 persen dari pertumbuhan ekonomi Indonesia. Dari survey Nielson pada kuartal pertama 2018, sekitar 77 persen konsumen menyatakan lebih mementingkan belanja makananan (Marsudiyanto:2009).

Siring dengan hal tersebut kota Tanjungpinang yang memiliki keanekaragaman makanan khas yang memiliki cita rasa dan kualitas yang tidak kalah dengan makanan khas daerah lainnya. Hal ini menjadi tantangan kota Tanjungpinang untuk lebih mengenalkan makanan khas Tanjungpinang, sehingga makanan khas kota Tanjungpinang bisa dikenal oleh konsumen tidak hanya lokal, tetapi juga nasional bahkan sampai tingkat internasional.

Para wisatawan yang mengunjungi kota Tanjungpinang belum banyak yang mengetahui sepenuhnya makanan khas apa saja yang dalam kemasan dan menggambarkan kualitas produknya. Hal ini akan berdampak pada UMKM atau industri rumah tangga yang yang memiliki usaha makanan khas Tanjungpinang, meski pemerintah telah melakukan peningkatan usaha baik langsung maupun tidak langsung terhadap UMKM yang ada di kota Tanjungpinang.

Pertumbuhan bisnis toko yang menjual makanan khas melayu atau Tanjungpinang telah menyebar sampai kepelosok kota Tanjungpinang, maka di Tanjungpinang makanan khas ini telah menjadi icon oleh-oleh bagi wisatawan atau pelanggan yang mengunjungi kota Tanjungpinang. Hal ini telah menjadi salah satu wisata kuliner Kota Tanjungpinang bahkan telah menyebar hampir di seluruh pelosok kota Tanjungpinang. Berbagai jenis makanan dikemas sedemikian rupa, sehingga bisa menarik pengunjung/konsumen.

Salah satu faktor penting dalam penjualan produk adalah kualitas produk, karena konsumen akan merasa puas jika kualiats produk sesuai dengan harapannya dan kemasannya (packaging), karena konsumen akan akanmelakukan pembelian apabila kualitas produk dan kemasannya dapat memberikan kepuasan kepada konsumen. Pemasar dituntut untuk kreatif dan inovatif agar dapat menarik perhatian konsumen dan membawa minat dari konsumen untuk membeli produk yang ditawarkan (Iranita, 2019).

Konsumen dapat mengambil keputusan untuk membeli sebuah barang atau jasa ketika konsumen tersebut menganggap produk itu dibutuhkan. Kualitas produk yang diberikan perusahaan adalah strategi yang tepat untuk menarik perhatian konsumen. Hal ini di dukung oleh penelitian yang dilakukan oleh Anwar (2015) yang menunjukkan bahwa kualitas produk berpengaruh terhadap keputusan pembelian.

Selain dari kualitas produk, penjualan meningkat juga dipengaruhi oleh kemasan. Hal ini sesuai dengan yang diungkapkan oleh Christie Suharto Cenadi dalam Dhameria (2014), bahwa daya tarik suatu produk tidak dapat terlepas dari kemasannya. Kemasan merupakan pemicu karena ia langsung berhadapan dengan konsumen. Karena itu kemasan harus dapat mempengaruhi konsumen untuk memberikan respon positif.

Ada tuntutan dari konsumen untuk mendapatkan informasi yang layak sehingga memperkecil resiko negative pasca konsumsi. Seperti diketahui, produk makanan merupakan produk dengan keterlibatan tinggi. Studi lain dilakukan oleh Point of Purchase Advertising Institute, menunjukkan bahwa sekitar 52,6\% dari pembelian produk makanan di toko swalayan, tidak direncanakan secara spesifik di benak konsumen (Aruman, 2008).

Faktor kemasan (packaging) memegang peranan penting dalam keputusan pembelian konsumen. Kemasan (packaging) menjadi lebih salah satu dipertimbangkan oleh perusahaan dewasa ini. Perusahaan semakin menyadari arti penting kemasan bagi suksesnya sebuah produk.

Oleh karena itu, aktivitas-aktivitas strategi dalam mengelola kemasan, meliputi penciptaan kemasan, membangun kemasan, memperluas kemasan untuk memperkuat posisi kemasan menjadi perhatian produsen. Semua dilakukan agar kemasan yang dimiliki oleh perusahaan dapat menjadi kekayaan atau ekuitas bagi perusahaan. 
Kemasan juga berlaku sebagai alat untuk diferensiasi dan membantu konsumen untuk memutuskan produk dari berbagai macam produk paralel, serta kemasan juga merangsang perilaku pembelian pelanggan (Wells, Farley \& Armstrong, 2007 dalam Raheem, Vishnu, \& Ahmed, 2014).

Sesuai dengan urain diatas, maka peneliti menganggap ini sebagai tantangan yang perlu rumuskan, dijaki dan diteliti secara mendalam untuk menyusun dan menemukan model, sehingga peneliti tertarik meneliti dengan judul "Analisis Faktor-Faktor Kemasan (Packaging) Dalam Mempengaruhi Keputusan Pembelian Oleh-oleh Makanan Khas Tanjungpinang"

\section{Tujuan Penelitian}

Berdasarkan rumusan masalah yang telah disebutkan sebelumnya maka penelitian ini bertujuan untuk menganalisis dan mengetahui faktor-faktor kemasan (packaging) dalm mempengaruhi keputusan pembelian oleh-oleh makanan khas Tanjungpinang.

\section{Kemasan (Packaging)}

Menurut Rundh dalam Darmawan (2017), pentingnya kemasan dan desain kemasan untuk memenuhi kriteria multi-fungsi yang berkaitan dengan logistik dan pemasaran dalam rantai pasokan yang diakhiri di tangan konsumen sehingga memunculkan fenomena perubahan pola konsumsi dan kebiasaan yang membutuhkan solusi kemasan yang inovatif. Hal ini sesuai dengan yang diungkapkan oleh Kotler dan Amstrong (2014) yang menyatakan bahwa kemasan adalah semua kegiatan merancang dan memproduksi wadah untuk produk. Adapun unsur-unsur kemasan menurut Kotler dan Amstrong (2014) adalah ukuran, warna, bahan, bentuk, gambar, tanda merek dan label.

Banyak perusahaan yang sangat memperhatikan kemasan suatu produk sebab perusahaan menganggap bahwa fungsi kemasan tidak hanya sebagai pembungkus tetapi lebih luas dari pada itu. Pengemasan harus mengandung fungsi daya tarik dan daya lindung. Perubahan kemasan sering pula memunculkan kesan dari konsumen karena mereka beranggapan bahwa barang yang didalamnya juga ikut berubah.

Oleh sebab itu suatu kemasan harus dibuat semenarik dan seaman mungkin untuk memikat banyak konsumen untuk melakukan pembelian terhadap produk sehingga para konsumen bersedia membayar lebih tinggi hanya untuk mendapatkan kemasan khusus (Darmawan, 2017).

Dengan demikian jelaslah bahwa dengan kemasan yang menarik dapat mempengaruhi calon pembeli untuk melakukan pembelian karena kemasan yang menarik setidaknya mempunyai daya tarik dalam pandangan konsumen. Dengan perkataan lain bahwa kemasan berpengaruh terhadap keputusan pembelian.

\section{Faktor-Faktor Kemasan (Packaging) Produk}

Kemasan yang baik dan akan digunakan semaksimal mungkin dalam pasar harus mempertimbangkan dan dapat menampilkan beberapa faktor, antara lain sebagai berikut.

1. Faktor pengamanan.

Kemasan harus melindungi produk terhadap berbagai kemungkinan yang dapat menjadi penyebab timbulnya kerusakan barang, misalnya: cuaca, sinar matahari, jatuh, tumpukan, kuman, serangga dan lain-lain. Contohnya, kemasan biskuit yang dapat ditutup kembali agar kerenyahannya tahan lama.

2. Faktor ekonomi.

Perhitungan biaya produksi yang efektif termasuk pemilihan bahan, sehingga biaya tidak melebihi proporsi manfaatnya. Contohnya, produk-produk refill atau isi ulang, produkproduk susu atau makanan bayi dalam karton, dan lain-lain.

3. Faktor pendistribusian.

Kemasan harus mudah didistribusikan dari pabrik ke distributor atau pengecer sampai ke tangan konsumen. Di tingkat distributor, kemudahan penyimpanan dan pemajangan perlu dipertimbangkan. Bentuk dan ukuran kemasan harus direncanakan dan dirancang sedemikian rupa sehingga tidak sampai menyulitkan peletakan di rak atau tempat pemajangan. 
4. Faktor komunikasi. Sebagai media komunikasi kemasan menerangkan dan mencerminkan produk, citra merek, dan juga bagian dari produksi dengan pertimbangan mudah dilihat, dipahami dan diingat. Misalnya, karena bentuk kemasan yang aneh sehingga produk tidak dapat "diberdirikan", harus diletakkan pada posisi "tidur" sehingga ada tulisan yang tidak dapat terbaca dengan baik; maka fungsi kemasan sebagai media komunikasi sudah gagal.

5. Faktor ergonomic.

Pertimbangan agar kemasan mudah dibawa atau dipegang, dibuka dan mudah diambil sangatlah penting. Pertimbangan ini selain mempengaruhi bentuk dari kemasan itu sendiri juga mempengaruhi kenyamanan pemakai produk atau konsumen. Contohnya, bentuk botol minyak goreng Tropical yang pada bagian tengahnya diberi cekungan dan tekstur agar mudah dipegang dan tidak licin bila tangan pemakainya terkena minyak.

6. Faktor estetika.

Keindahan pada kemasan merupakan daya tarik visual yang mencakup pertimbangan penggunaan warna, bentuk, merek atau logo, ilustrasi, huruf, tata letak atau layout, dan maskot . Tujuannya adalah untuk mencapai mutu daya tarik visual secara optimal.

7. Faktor identitas.

Secara keseluruhan kemasan harus berbeda dengan kemasan lain, memiliki identitas produk agar mudah dikenali dan dibedakan dengan produk-produk yang lain.

8. Faktor promosi

Kemasan mempunyai peranan penting dalam bidang promosi, dalam hal ini kemasan berfungsi sebagai silent sales person. Peningkatan kemasan dapat efektif untukmenarik perhatian konsumen-konsumen baru.

9. Faktor lingkungan.

Kita hidup di dalam era industri dan masyarakat yang berpikiran kritis. Dalam situasi dan kondisi seperti ini, masalah lingkungan tidak dapat terlepas dari pantauan kita. Trend dalam masyarakat kita akhir-akhir ini adalah kekhawatiran mengenai polusi, salah satunya pembuangan sampah.

\section{Keputusan Pembelian}

\section{Pengertian Keputusan Pembelian}

Hampir seluruh perusahaan meneliti pengambilankeputusan pembelian konsumen secara mendetil untuk memperoleh jawaban apakonsumen beli, dimana mereka membelinya, bagaimana caranya dan seberapabanyak, kapan dan mengapa mereka membelinya.

Menurut Schiffman, Kanuk dalam Ansari (2015), bahwa keputusan pembelian adalah pemilihan dari dua atau lebih alternatif pilihan keputusan pembelian, artinya bahwa seseorang dapat membuat keputusan, harus tersedia beberapa alternatif pilihan. Keputusan untuk membeli dapat mengarah pada bagaimana proses dalam pengambilan keputusan tersebut itu dilakukan.

Sedangkan menurut Kotler (2013) menyatakan bahwa : "Keputusan pembelian adalah suatu proses penyelesaian masalah yang terdiri dari menganalisa kebutuhan dan keinginan, pencarian informasi, penilaian sumber-sumber seleksi terhadap alternatif pembelian, keputusan pembelian, dan perilaku setelah pembelian."

\section{Tahap Proses Keputusan Pembelian}

Dalam mempelajari keputusan pembelian konsumen, seorang pemasar harus melihat hal-hal yang berpengaruh terhadap keputusan pembelian dan membuat suatu ketetapan konsumen membuat keputusan pembeliannya. Kotler (2013:204) mengemukakan proses pembelian tersebut melalui lima tahapan. Tahapan pembelian konsumen tersebut antara lain adalah:

1. Pengenalan masalah (problem recognition) Proses pembelian diawali dengan adanya masalah atau kebutuhan yang dirasakan oleh konsumen

2. Pencarian informasi (information search) Konsumen mencari informasi baik yang disimpan dalam ingatan (internal) maupun 
informasi yang didapat dari lingkungan (eksternal).

3. Evaluasi alternatif (validation of alternativ)

Konsumen mengevaluasi berbagai alternatif pilihan dalam memenuhi kebutuhan tersebut

4. Keputusan Pembelian (purchase decision) Konsumen yang telah melakukan pilihan terhadap berbagai alternatif biasanya membeli produk yang paling disukai.

5. Perilaku pasca pembelian (post purchase behavior)

Kepuasan atau ketidak puasan konsumen terhadap suatu produk akan berpengaruh terhadap perilaku pembelian selanjutnya. Jika puas konsumen akan melakukan pembelian ulang sedang jika konsumen tidak puas maka akan menghentikan pembelian produk, bahkan melakukan persepsi buruk word of mouth terhadap produk.

\section{Indikator Keputusan Pembelian}

Indikator dari keputusan pembelian (dalam Soewito : 2013) :
a) Kebutuhan yang dirasakan
b) Kegiatan sebelum membeli
c) Perilaku waktu memakai
d) Perilaku pasca pembelian

Penelitian ini dilakukan untuk menguji ada atau tidaknya Pengaruh Faktor-faktor Kemasan (Packaging) Dalam Mempengaruhi Keputusan Pembelian Oleh-Oleh Makanan Khas Tanjungpinang"

\section{Kerangka Konseptual}

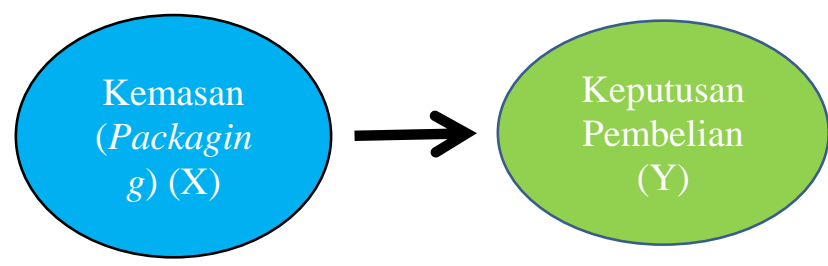

Gambar 1. Kerangka Konseptual

\section{Metode Penelitian}

\section{Desain Penelitian}

Pada penelitian ini peneliti mengambil lokasi di sekitar kota Tanjungpinang, dimana makanan khas yang dijual sebagai oleh-oleh Tanjungpinang baik itu yang tersedia di Swalayan atau pun Counter/Toko tersebar di seputaran kota Tanjungpinang. Pengambilan lokasi tersebut merujuk pada tujuan penelitian untuk mengetahui dan menganalisis faktor - faktor kemasan (packaging) oleh-oleh makanan khas Tanjungpinang terhadap keputusan Pembelian.

Penelitian yang digunakan disini adalah penelitian yang bersifat eksplorasi (explanatory research) yaitu penelitian yang menggali dan menganalisis faktor - faktor kemasan (packaging) dalam mempengaruhi keputusan pembelian oleholeh makanan khas kota Tanjungpinang.

Metode pengumpulan data pada dasarnya ada 3 macam, yaitu sensus, sampling, dan studi kasus (case study). Pada penelitian ini digunakan metode sampling atau survei. Dimana metode pengumpulan data merupakan cara kerja yang bersistem dalam mengumpulkan data untuk mencapai tujuan penelitian, yang dilakukan melalui survei dan analisa karena penelitian merupakan aktivitas ilmiah yang sistematis, terarah dan bertujuan,dengan melakukan wawancara dan kuesioner.

\section{Populasi Dan Sampel}

Unit populasi penelitian (research population) adalah konsumen yang membeli oleh-oleh makanan khas Tanjungpinang sebagai oleh-oleh pada Swalayan dan Counter penyedia makanan khas seagai oleh-oleh di Tanjungpinang. Sedangkan Pengambilan sampel yang penulis lakukan adalah menggunakan Accidental Sampling yaitu teknik penentuan sampel berdasarkan kebetulan bertemu dengan responden dapat digunakan sebagai sampel, bila dipandang orang yang kebetulan ditemuinya itu cocok sebagai sumber data (Sugiono, 2014).

Digunakan teknik acidental sampling tersebut adalah dengan pengertian bahwa tidak mungkin semua populasi dapat di interview, karena 
keterbatasan tenaga, waktu dan biaya, anggota populasi lainnya dianggap homogen. Homogen dalam pengertian sampel ini adalah responden yang memiliki kesamaan dalam dalam membeli makanan khas sebagai oleh-oleh Tanjungpinang. Setelah dilakukan perhitungan diperoleh sampel sebanyak 60 responden.

\section{Pengumpulan Data}

Kuesioner disebarkan kepada tiga puluh (60) konsumen yang membeli makanan khas Tanjungpinang sebagai oleh-oleh. Hasilnya didapat atribut-atribut apa saja dari kemasan (packaging) yang menurut konsumen mempengaruhi keputusan mereka dalam membeli oleh-oleh makanan khas Tanjungpinang.

\section{Metode Analisis}

Untuk menjawab masalah dan mengungkap tujuan penelitian ini analsisi yang digunakan adalah analisis faktor yang digunakan untuk mengetahui faktor-faktor apa yang mempengaruhi keputusan konsumen dalam membeli makanan khas Tanjungpinang. Analisis faktor yaitu suatu metode reduksi data untuk menemukan variabel baru yang disebut faktor yang jumlahnya lebih sedikit dibandingkan dengan jumlah aslinya, yang tidak berkorelasi satu sama lainnya, variabel baru tersebut memuat sebanyak mungkin informasi yang terkandung di dalam variabel asli (Kuncoro,2009)

Menurut Sarwono (2006) Model analisis faktor dinyatakan dengan formula sebagai berikut :

$\mathrm{Xi}=\mathrm{Aij}+\mathrm{Ai} 2 \mathrm{~F} 2+\mathrm{Ai} 3 \mathrm{~F} 3 \ldots+\mathrm{AimFm}+$ ViUi dimana :

$\mathrm{Xi}=$ Variable standar yang ke- $\mathrm{i}$

Aij = Koefisien Multiple Regresi Standar dari variabel ke-i pada common faktor $\mathrm{j}$

$\mathrm{F}=$ Common Factor

$\mathrm{Vi}=$ Koefisien regresi berganda standar dari variabel-i pada faktor unik-i

$\mathrm{Ui}=$ Faktor unik variabel-i

$\mathrm{m}=$ Banyaknya common factor Faktor unik berkorelasi satu dengan yang lain dan dengan common factor.
Common factor dapat dinyatakan sebagai kombinasi linier dari variabel yang diteliti, dengan persamaaan :

$\mathrm{Fi}=\mathrm{Wi} 1 \mathrm{X} 1+\mathrm{Wi} 2 \mathrm{X} 2+\mathrm{Wi} 3 \mathrm{X} 3+\ldots .+$ WikXk dimana :

$\mathrm{Fi}=$ Faktor ke-i yang diestimasi

$\mathrm{Wi}=$ Bobot atau koefisien score factor

$\mathrm{Xk}=$ Banyaknya variabel $\mathrm{X}$ pada faktor $\mathrm{ke} \mathrm{k}$

\section{Statistik Yang Terkait Analisis Faktor}

Prosedur melakukan Analisis Faktor :

- Barlett's test of sphrecity. Uji yg dugunakan utk menguji hipotesis bhw variabel 2 tdk saling berkorelasi $\mathrm{dlm}$ populasi. Matriks korelasi populasi mrpkn matriks identitas, setiap varibael berkorelasi scr sempurna dg dirinya sendiri $(r=1)$ dan tidak berkorelasi dg yg lain $(\mathrm{r}=0)$

- Factor loading (muatan faktor). Merupakan korelasi sederhana antara variabel2 dgn faktor2 atau antara variabel baru dgn variabel yg diwakilinya

- Eigen Value (nilai eigen). Nilai eigen mewakili varians total yg dijelaskan oleh setiap faktor. Dilihat dr R2 => berapa \% varian dr sejumlah varian dpt dijelskan dgn faktor. Mis: Variabel 1 memiliki hub yg kuat dgn faktor 1

Mis: hub F1 dgn V1 V2 V3 adl R2 $=0.81$ Maka faktor 1 dpt menjelaskan V1 V2 V3 sebesar $81 \%$

- Rotasi. Memutar faktor yg ada agar memudahkan interpretasi.

- Component matrix. Utk melihat variabel2 mana yg masuk dlm komponen 1 atau 2

- Kaiser Meyer Olkin (KMO). Ukuran sampling KMO menetukan apakah variabel2 yg kita uji bisa dianalisis atau tidak. Jika nilai dibaah 0,5 maka tidak bisa dianalisis. Nilai tinggi $(0,5-$ 1) $=>$ analisis faktor telah cukup. Nilai $<0,5=>$ analisis faktor tidak cukup

- Anti image matrix. Yaitu cara melihat diagonal ke bawah atau ke atas. Jika nilai anti images nya kurang dari 0.5 maka variabel tsb harus dibuang. Maka prosesnya harus diulang, 
dibuang satu per satu hingga tdk ada nilai yg dibawah 0,5

\section{Tahapan Analisis Faktor}

1. Tabulasi data pada data view,

2. Pembentukan matrik korelasi,

3. Ekstraksi faktor,

4. Rotasi faktor, dan

5. Penamaan faktor yang terbentuk.

Seluruh proses pengolahan data, mempergunakan alat bantu SPSS versi 23 for windows.

\section{Hasil dan Pembahasan}

\section{Uji Kualitas Data}

\section{Hasil Uji Validitas}

Tabel 1. Hasil Pengujian Validitas

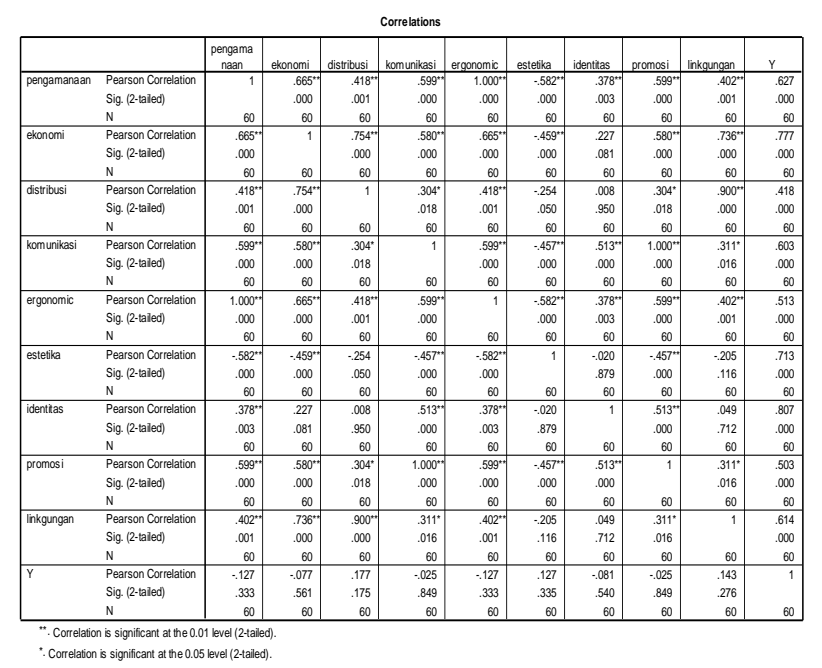

Sumber: data diolah, 2020

Uji signifikan dilakukan dengan membandingkan nilai $r$ hitung dengan $r$ tabel untuk degree of freedom $(\mathrm{df})=\mathrm{n}-2$, dimana sampel pada penelitian ini adalah 60 responden maka df nya dengan sig 0,05 adalah 0,2542 .

Berdasarkan data hasil penelitian pada tabel 1 di atas dapat dijelaskan bahwa dari 4 (empat) pernyataan di atas dinyatakan valid dan layak dijadikan instrument dalam penelitian ini dimana semua $r$ hitung item pernyataan lebih besar dari $r$ tabel yaitu 0,2542 .

\section{Hasil Uji Reliabilitas}

Menurut Ghozali (2013:47) bahwa reliabilitas sebenarnya adalah alat untuk mengukur suatu kuesioner yang merupakan indikator dari variabel atau kontruks. Suatu kuaesioner dikatakan reliabel atau handal jika jawaban seseorang terhadap pernyataan adalah konsisten atau stabil dari waktu ke waktu. Suatu kontruks atau variabel dikatakan reliabel jika memberikan nilai Cronbach's Alpha > 0,70, maka indikator yang terdapat pada suatu kuesioner dapat dikatakan reliabel. Berikut hasil uji reliabilitas dalam penelitian untuk setiap variabel dapat dilihat pada tabel dibawah ini:

Tabel 2. Hasil Pengujian Reliabilitas

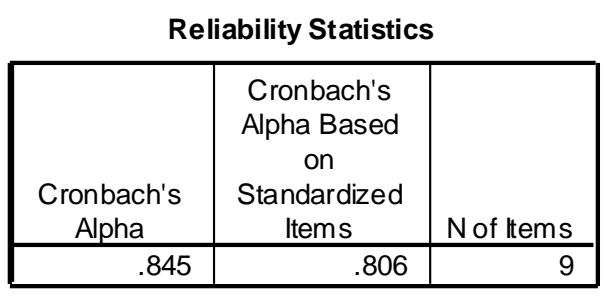

Sumber: data diolah, 2020

Berdasarkan data tabel.1 dapat disimpulkan bahwa Cronbach Alpha Kemasan Produk bernilai 0,845 yang berarti $>0,70$.

\section{Intreprestasi Faktor Kemasan (Packaging)}

Data ini diolah dengan alat bantu software SPSS 16.0. kesembilan variabel yang telah dianggap valid dan reliabel, kemudian dimasukan ke dalam analisis faktor untuk diuji apakah nilainya lebih besar dari nilai KMO dan Barlett's Testyangdi atas 0,5, hal ini merupakan tahap awal dalam analisis faktor. Berikut ini adalah tahap-tahap analisis faktor pada penelitian ini.

\section{Tahap1:}

Tahap awal dalam analisis faktor adalah Uji KMO dan bartlett's test dilakukan untuk mengetahui apakah faktor-faktor dalam penelitian valid atau tidak, pada tahap ini angka KMO dan Barlette's Test harus di atas $(0,5)$ dengan ktriteria: 
1. $\mathrm{MSA}=1$, variabel tersebut dapat diprediksi tanpa kesalahan oleh variabel yang lain

2. MSA $>0,5$, variabel masih bisa diprediksi dan bisa dianalisis lebih lanjut.

3. MSA $<0,5$, variabel tidak bisa diprediksi dan tidak bisa dianalisis lebih lanjut, atau dikeluarkan dari variabel lainnya

Pada tabel 1.1 dapat dijelaskan bahwa tabel KMO and Bartlett's test menujukkan angka KMO Measure of sampling Adequaci (MSA) untuk Faktor Kemasan (Packaging) adalah 0,751 $(>0,5)$ dengan (Sig) 0,000 $(<0,05)$. Hal ini menunjukkan kecukupan dan variabel memiliki korelasi yang kuat, data bisa dilanjutkan.

Tabel 3. KMO and Bartlett's Test

KMO and Bartlett's Test

\begin{tabular}{|c|c|c|}
\hline \multicolumn{2}{|c|}{$\begin{array}{l}\text { Kaiser-Meyer-Olkin Measure of Sampling } \\
\text { Adequacy. }\end{array}$} & .751 \\
\hline \multirow{3}{*}{$\begin{array}{l}\text { Bartlett's Test of } \\
\text { Spheric ity }\end{array}$} & Approx. Chi-Square & 321.723 \\
\hline & & 36 \\
\hline & Sig. & .000 \\
\hline
\end{tabular}

Sumber: data diolah, 2020

\section{Tahap 2:}

Selanjutnya untuk mengetahui variabel mana yang dapat diproses lebih lanjut dan mana yang dikeluarkan dapat dilihat pada tabel Anti-image matrices. Pada tabel Anti-image Matrice di bawah, khusus pada bagian (Anti Image Correlation) terlihat angka yang bertanda (a) yang menandakan besaran MSA sebuah variabel. Variabel Pengamanan 0.801, Ekonomi 0.824, distribusi 0.7681, komunikasi 0.735 , ergonomic 0.632 , estetika 0.722 , identitas 0.707 , promosi 0.634 , dan lingkungan 0.750 . Nilai MSA masing-masing variabel besarnya $>0.5$ maka semua variabel dapat diproses lebih lanjut.

\section{Tabel.4.Anti -image Matrices}

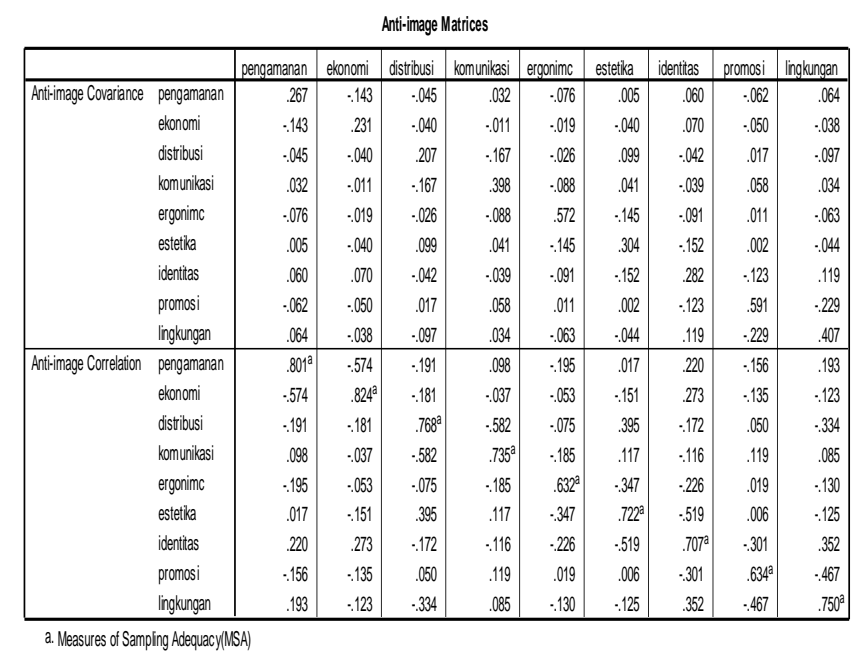

Sumber: data diolah, 2020

\section{Tahap 3:}

Analisis communalities, analisis ini pada dasarnya adalah jumlah varians (bisa dalam presentase ) dari suatu variabel mula-mula yang bisa dijelaskan oleh faktor yang ada. persyaratan nilai communalities sendiri adalahlebih besar dari 0,5 (Santoso,2011). Berikut adalah hasil analisis communalities dari 17 variabel yang tersisa dan bisa dilakukan pengujian lebih lanjut.

\section{Tabel.5. Communaties}

\begin{tabular}{|l|c|r|}
\hline & \multicolumn{3}{c}{ Communalities } \\
\hline pengamanan & 1.000 & Extraction \\
ekonomi & 1.000 & .721 \\
distribusi & 1.000 & .796 \\
komunikasi & 1.000 & .854 \\
ergonimc & 1.000 & .786 \\
estetika & 1.000 & .825 \\
identitas & 1.000 & .831 \\
promosi & 1.000 & .736 \\
lingkungan & 1.000 & .679 \\
\hline
\end{tabular}
Extraction Method: Principal Component Analysis.

Sumber: data diolah,2020 
Dari Tabel Communalities dapat dijelaskan bahwa variabel pengamanan besarnya $0,721>0,50$. Nilai extraction untuk semua variabel lebih besar dari 0,05, dengan demikian dapat disimpulkan bahwa semua varibel dapat dipakai untuk menjelaskan faktor.

Hal ini berarti sekitar $72,1 \%$ varians dari variabel pengamanan dapat dijelaskan oleh faktor yang terbentuk. Variabel ekonomi 0,796 hal ini berarti $79,6 \%$ varian dari variabel ekonomi dapat dijelaskan oleh faktor yang terbentuk. Demikian juga untuk variabel yang lain. Semakin kecil nilai communalities berarti semakin lemah hubungannya dengan faktor yang terbentuk

\section{Tahap 3:}

Proses selanjutnya dari analisis faktor adalah melakukan pengujian Total Variance Explained. Menurut Santoso (2011 :85), bahwa tabel Total Variance Explained menggambarkan jumlah faktor yang terbentuk. Jumlah angka eigenvalue susunanya selalu diurutkan pada nilai yang terbesar sampai yang terkecil. Berikutmerupakan tabel hasil uji total variance explained sebagai berikut:

Tabel.6. Total Variance Explained

\begin{tabular}{|c|c|c|c|c|c|c|c|c|c|}
\hline \multirow[b]{3}{*}{ Component } & \multicolumn{9}{|c|}{ Total Variance Explained } \\
\hline & \multicolumn{3}{|c|}{ Intila Eigenvalues } & \multicolumn{3}{|c|}{ Extraction Sums of Souared Loadings } & \multicolumn{3}{|c|}{ Rotation Sums of Souared Loadings } \\
\hline & Total & \% of Variance & Cumulative $\%$ & Total & $\%$ of Variance & Cumulative $\%$ & Total & \% of Variance & Cumulative $\%$ \\
\hline 1 & 4.225 & 46.940 & 46.940 & 4.225 & 46.940 & 46.940 & 2.722 & 30.243 & 30.243 \\
\hline 2 & 1.750 & 19.443 & 66.382 & 1.750 & 19.443 & 66.382 & 2.325 & 25.830 & 56.072 \\
\hline 3 & 1.124 & 12.484 & 78.867 & 1.124 & 12.484 & 78.867 & 2.052 & 22.795 & 78.867 \\
\hline 4 & .679 & 7.550 & 86.417 & & & & & & \\
\hline 5 & .439 & 4.876 & 91.293 & & & & & & \\
\hline 6 & .298 & 3.312 & 94.605 & & & & & & \\
\hline 7 & .208 & 2.314 & 96.919 & & & & & & \\
\hline 8 & .151 & 1.677 & 98.596 & & & & & & \\
\hline 9 & .126 & 1.404 & 100.000 & & & & & & \\
\hline
\end{tabular}

Sumber: data diolah, 2020

Pada tabel Total Variance Explained di atas menunjukkan ada 3 faktor yang terbentuk dari 9 variabel yang di masukkan. Masing-masing faktor eigenvalue $>1$. Faktor 1 eigen value sebesar 4,225 dengan variance $(46,94 \%)$, Faktor 2 eigenvalue sebesar 1,750 dengan variance $(19,44 \%)$, dan Faktor 3 eigenvalue sebesar 1,124 dengan $(12,48 \%)$.

Nilai eigenvalue menggambarkan kepentingan relatif masing-masing faktor dalam menghitung varians dari 9 variabel yang di analisis. Bila semua variabel dijumlahkan bernilai 9 (sama dengan banyaknya variabel).

$4,225 / 9 \times 100 \%=46,94 \%$

$1,750 / 9 \times 100 \%=19,44 \%$

$1,124 / 9 \times 100 \%=12,48 \%$

Total varians apabila dari 9 variabel diekstrak menjadi 3 faktor adalah :

$46,94 \%+19,44 \%+12,48 \%=78,86 \%$

Besarnya varians yang mampu dijelaskan oleh faktor baru yang terbentuk adalah 78,86\% sedangkan sisanya $21,14 \%$ dijelaskan oleh faktor lain yang tidak diteliti.

Langkah selanjutnya akan dijelaskan dalam grafik Screeplot yang akan menerangkan bahwa hubungan antara banyaknya faktor yang terbentuk dengan nilai eigenvalue dalam bentuk grafik.

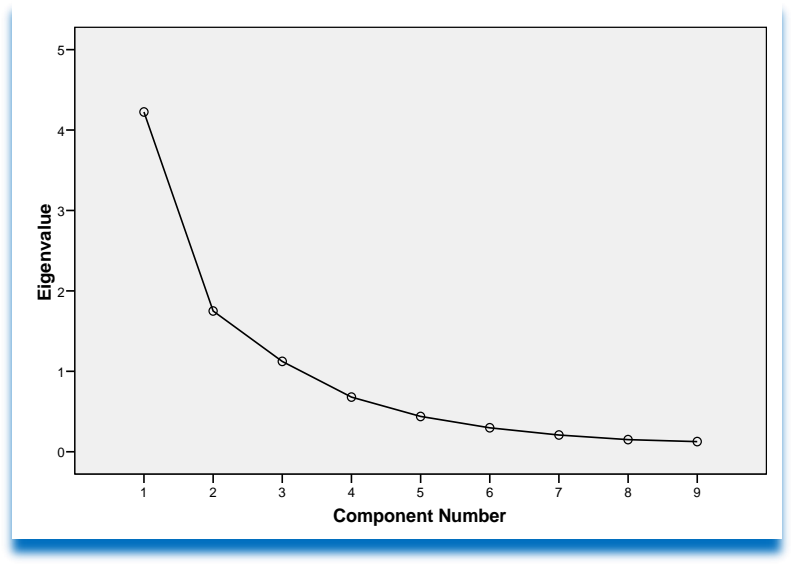

Sumber: data diolah,2020

Gambar 2. Grafik Scree Plot

Gambar Scree Plot di atas dapat menunjukkan faktor yang terbentuk.dimana nilai eigenvalue $>1$. Dari gambar 1 ada 2 titik Component yang memiliki nilai Eigenvalue $>1$ maka diartikan bahwa 2 faktor yang dapat terbentuk yaitu faktor pengamaan dan ekonomi.

\section{Tahap 4:}

Tahapan selanjutnya adalah menentukan itemitem yang dominan pada setiap komponen tersebut. Hal ini dapat dilihat dari tabel Component Matrix yang menunjukan distribusi item penelitian kelima 
faktor yang terbentuk. Kemudian dilakukan rotasi untuk menjelaskan distribusi variabel yang lebih jelas dan nyata, dibawah ini merupakan tabel yang menunjukkan hasil rotasi untuk memperjelas posisis sebuah variabel pada sebuah faktor.

Rotated Component matrix nilai loading faktor dari tiap-tiap variabel. Loading faktor merupakan besarnya korelasi antara faktor yang terbentuk dengan variabel tersebut. Rotasi yang dipakai adalah dengan metode varimax. Mekanisme rotasi varimax adalah dengan membuat korelasi item hanya dominan terhadap satu faktor.

\section{Tabel.7. Rotated Component Matrix}

\begin{tabular}{|c|c|c|c|}
\hline \multicolumn{4}{|c|}{ Rotated Component Matri民 } \\
\hline & \multicolumn{3}{|c|}{ Component } \\
\hline & 1 & 2 & 3 \\
\hline pengamanan & .692 & .426 & -.246 \\
\hline ekonomi & .742 & .432 & -.244 \\
\hline distribusi & .420 & .801 & -.224 \\
\hline komunikasi & .063 & .922 & .000 \\
\hline ergonimc & .288 & .367 & .754 \\
\hline estetika & -.120 & -.451 & .780 \\
\hline identitas & -.394 & -.219 & .793 \\
\hline promosi & .812 & -.137 & .242 \\
\hline lingkungan & .775 & .246 & -.135 \\
\hline
\end{tabular}

Sumber: data diolah, 2020

Untuk Rotated Component matrix dapat dijelaskan sebagai berikut:

1. Variabel pengamanan nilai korelasi pengamanan dengan faktor1 $(0,692)$, faktor2 $(0,426)$, dan faktor3 (-0,246), maka pengamanan masuk ke dalam Faktor 1, karena korelasinya paling tinggi diantara faktor yang lain.

2. Variabel ekonomi nilai korelasi ekonomi dengan faktor1 $(0,742)$, faktor2 $(0,432)$, dan faktor3 (-0,244), maka ekonomi masuk ke dalam Faktor 1, karena korelasinya paling tinggi diantara faktor yang lain

3. Variabel distribusi nilai korelasi distribusi dengan faktor1 $(0,420)$, faktor2 $(0,801)$, dan faktor3 $(-0,224)$, maka distribusi masuk ke dalam Faktor 2, karena korelasinya paling tinggi diantara faktor yang lain.
4. Variabel komunikasi nilai korelasi komunikasi dengan faktor1 $(0,063)$, faktor2 $(0,922)$, dan faktor3 (0,000), maka komunikasi masuk ke dalam Faktor 2, karena korelasinya paling tinggi diantara faktor yang lain

5. Variabel ergonomic nilai korelasi ergonomic dengan faktor1 $(0,288)$, faktor2 $(0,367)$, dan faktor3 $(0,754)$, maka ergonomic masuk ke dalam Faktor 3, karena korelasinya paling tinggi diantara faktor yang lain

6. Variabel estetika nilai korelasi estetika dengan faktor1 $(0,120)$, faktor2 $(0,451)$, dan faktor3 $(0,780)$, maka estetika masuk ke dalam Faktor3, karena korelasinya paling tinggi diantara faktor yang lain

7. Variabel identitas nilai korelasi identitas dengan faktor1 $(0,394)$, faktor2 $(0,219)$, dan faktor3 (0,793), maka identitas masuk ke dalam Faktor 3, karena korelasinya paling tinggi diantara faktor yang lain

8. Variabel promosi nilai korelasi promosi dengan faktor1 $(0,812)$, faktor2 $(0,137)$, dan faktor3 $(0,242)$, maka promosi masuk ke dalam Faktor 1, karena korelasinya paling tinggi diantara faktor yang lain

9. Variabel lingkungan nilai korelasi lingkungan dengan faktor1 $(0,775)$, faktor2 $(0,246)$, dan faktor3 (0,13542), maka lingkungan masuk ke dalam Faktor 1, karena korelasinya paling tinggi diantara faktor yang lain

Tabel.8. Component Transformation Matrix

Component Transformation Matrix

\begin{tabular}{|l|r|r|r|}
\hline Component & \multicolumn{1}{|c|}{1} & \multicolumn{1}{|c|}{2} & \multicolumn{1}{l|}{3} \\
\hline 1 & .688 & .622 & -.373 \\
2 & .456 & .630 & .890 \\
3 & -.565 & .782 & .763 \\
\hline
\end{tabular}

Extraction Method: Principal Component Analysis. Rotation Method: Varimax with Kaiser Normalization.

Sumber: data diolah, 2020

Tabel Component Transformation Matrix diatas menunjukkan bahwa pada component 1 nilai korelasinya adalah sebesar 0,688 >0,5, component 2 nilai korelasinya sebesar $0,630>0,5$ dan component 3 nilai korelasinya sebesar 0,763 . 
Setelah dilakukan rotasi dan terbentuk 3 faktor, selanjutnya memberi nama faktor tersebut. Penamaan faktor ini tergantung peneliti dan dapat mewakili variabel-variabelnya.

1. Faktor 1 terdiri dari variabel pengamanan, ekonomi, promosi dan lingkungan. Diberi nama LINGKUNGAN DAN PROMOSI

2. Faktor 2 terdiri dari distibusi dan komunikasi. Diberi nama JARINGAN DISTRIBUSI

3. Faktor 3 terdiri dari ergonomic, estetika, identitas. Diberi nama ESTETIKA DAN IDENTITAS

\section{Kesimpulan}

Dari hasil analisis terlihat bahwa nilai KMO MSA (Keiser Meyer OlkinMeasure of Sampling Adequacy) pada tabel adalah 0.751. Hasil menunjukkan bahwa instrumen valid karena nilai KMO MSA (Keiser Meyer Olkin Measure of Sampling Adequacy) melebihi batas signifikansi 0.50. Selain itu,Bartlett's Test of Sphericity menunjukkan nilai 321,723 dengan signifikansi 0,000 sehingga dapat diambil kesimpulan bahwa instrumen cukup valid. Dari 9 butir pertanyaan yang di analisis dan setelah melewati analisis KMO MSA, ternyata dari hasil analisis ekstraksi komputer menjadi 3 faktor (nilai eigen value $>1$ menjadi 3 faktor). Faktor 1 mampu menjelaskan 46,94\% variasi, faktor 2 mampu menjelaskan 19,94\% variasi, dan faktor 3 mampu menjelaskan $12,48 \%$ variasi. Dari hasil rotasi dapat dilihat bahwa 9 variabel tersebut dapat direduksi menjadi 3 faktor yaitu : faktor pengamanan, faktor ekonomi, faktor promosi dan faktor lingkungan meliputi variabel lingkungan dan promosi, Faktor distribusi dan komunikasi meliputi variabel jaringan distribusi, faktor ergonomic, estetika dan identitas meliputi variabel estetika dan identitas

\section{Daftar Pustaka}

Ahmed, R. R., Parmar, V., \& Amin, M. A. (2014). Impact of Product Packaging on Consumer " $s$ Buying Behavior. European Journal of Scientific Research, 120(March), 145-157.
Akbar, A. 2012. Analisis Pengaruh Citra Merek, Harga, Dan Kualitas Produk Terhadap Keputusan Pembelian Notebook Toshiba. Fakultas Ekonomi. Jurusan Manajemen Universitas Gunadarma, Jakarta

Anis, Liya Monalisa. 2015. Pengaruh Kualitas Produk Terhadap Internasional Brand Image Serta Dampaknya Terhadap Keputusan Pembelian. Jurnal Administrasi Bisnis (2015), Vol. 28, No. 2, November 2015

Anwar, Iful. 2015. Pengaruh Harga Dan Kualitas Produk Terhadap Keputusan Pembelian "Bunchbead Kota Malang". Jurnal Ilmu dan Riset Manajemen. Vol. 4, No. 12 (2015). ISSN: 2461-0593

Aruman, 2008, "The Power Of Silent Salesman" Mix Marketing, Edisi 15 September -12 Okrober, hal 22-24

Cahyorini, A., \& Rusfian, E. Z., 2011, Effect of Packaging Design on Impulsive Buying. Journal of Administrative Science and Organization, 18(1), 11-21.

Darmawan, Didit, 2017, Pengaruh Kemasan Dan Harga Terhadap Keputusan Pembelian Produk Sayuran Hidroponik, Agrimas, April 2017, Volume 1 Nomor 1

Dhameria, V. (2014). Analisis pengaruh keunikan desain kemasan produk, kondusivitas Store Environment, Kualitas Display Produk Terhadap Keputusan Pembelian Impulsif (Studi Pada Pasaraya Sri Ratu Pemuda Semarang). Jurnal Sains Pemasaran Indonesia, XIII(1), 1-44

Ghozali, Imam, 2016, Aplikasi Analisis Multibariete Dengan Program IBM SPSS Universitas Diponegoro.

Giardo Permadi Putra Zainul Arifin Sunarti, 2017, Fakultas Ilmu Administrasi Universitas Brawijaya Malang, Jurnal Administrasi Bisnis, (JAB)| Vol.48 No.1 Juli2017, administrasibisnis.studentjournal.ub.ac.id

Hidayat, M. J., 2011, Tinjauan Kognisi Desain produk Kemasan Sebagai unsur Identitas Budaya Populer Atas Produk Kemasan 
Makanan Industri Kecil Menengah (IKM). Kawistara, 1(3), 213-320.

Iranita, 2019, Analisis Pengaruh Brand Equity Untuk Meningkatkan Minat Beli Ulang Dan Word Of Mouth (Studi Kasus Batik Gonggong Tanjungpinang), Vol.3. nomor 2.2019, hal.40-55, Bahtera Inovasi, ISSN.2613-9243

Kotler, P.,\& Armstrong.G, 2014, Prinsip-prinsip Pemasaran Jilid 1 (13 ${ }^{\text {th }}$ Ed), Jakarta : Erlangga

, 2013, Manajemen Pemasaran, Jilid $2\left(13^{\text {th }}\right.$ Ed), Jakarta: Erlangga

Kuncoro, Mudrajat, 2009, Metode Riset untuk Bisnis dan Ekonomi,,Jakarta : Erlangga

Marsudiyanto, 2009, Masyarakat Indonesia lebih mementingkan Kebutuhan Makanan (online), http://caricara.com, diakses pada 19 Desember 2019)

Raheem, A. R., Vishnu, P., \& Ahmed, A. M. 2014. Impact of Product Packaging on Consumer's Buying Behavior. European Journal of Scientific Research, 122,

Sarwono,Jonathan, 2006, Metode Penelitian Kuantitatif Dan Kualitatif., Yogyakarta: Graha Ilmu, hal. 202.

Soewito, Yudhi. 2013. Kualitas Produk, Merek dan Desain Pengaruhnya Terhadap Keputusan Pembelian Sepeda Motor Yamaha Mio. Jurnal Ekonomi. Vol.1, No.3 Juni 2013.

Sugiono, 2014, Metode Penelitian Manajemen, Bandung:Alfabeta

Tjiptono, Fandy, 2014, Pemasaran Jasa, Penerbit Andi, Yokyakarta 